\title{
HNRNPD Gene
}

National Cancer Institute

\section{Source}

National Cancer Institute. HNRNPD Gene. NCI Thesaurus. Code C102830.

This gene is involved in RNA catabolism. 